\title{
Mengembangkan Kemampuan Menulis Narasi Berdasarkan Teks Wawancara
}

\author{
Endang Iryani \\ Universitas MH Thamrin \\ endang.umht@gmail.com
}

\begin{abstract}
ABSTRAK
Ketrampilan menulis masih dianggap sebagai hal yang menyulitkan bagi siswa, padahal kemampuan menulis merupakan kemampuan yang menunjang segala belajar, karena hampir semua pelajaran menggunakan tulisan dalam ujian dan tugas. Penelitian ini bertujuan mendeskripsikan kemampuan siswa dalam menulis, terutama mengembangkan karangan narasi berdasarkan teks wawancara. Metode yang digunakan adalah metode deskriptif kuantitatif. Sumber data penelitian ini adalah siswa kelas I SMAN 8 Tangerang sebanyak 48 siswa. Hasil penelitian ini membuktikan bahwa kemampuan siswa dalam mengembangkan karangan tersebut masih kurang. Dilihat dari segi persentase, siswa memperoleh nilai pada kategori sangat baik tidak ada, kategori baik 6 orang atau 12,5\%, kategori cukup 10 orang atau $20,8 \%$, kategori kurang 7 orang atau 14,5\% dan sisanya 25 orang atau 52,0\% sangat kurang. Adapun skor rata-rata yang diperoleh mereka adalah 45,39 dan dibulatkan menjadi 45. Dengan demikian kemampuan mengembangkan karangan narasi berdasarkan teks wawancara oleh siswa kelas I SMAN 8 Tangerang tergolong kurang.
\end{abstract}

\section{Pendahuluan}

Kemampuan berbahasa dalam KBK mencakup empat aspek penting, yaitu (1) keterampilan mendengar, (2) keterampilan berbicara, (3) keterampilan membaca, dan (4) keterampilan menulis. Kemampuan berbahasa ini berhubungan erat dalam usaha seseorang memperoleh kemampuan berbahasa yang baik. Berbagai usaha dilakukan untuk membina dan mengembangkan bahasa agar benar-benar memenuhi fungsinya.

Salah satu cara untuk meningkatkan kemampuan berbahasa Indonesia yang baik dan benar adalah melalui program pendidikan di sekolah, khususnya mata pelajaran Bahasa Indonesia. Menurut Depdiknas (2003:6-7), mata pelajaran Bahasa Indonesia bertujuan agar peserta didik memiliki kemampuan:

1) Berkomunikasi secara efektif dan efisien sesuai dengan etika yang berlaku, baik secara lisan maupun tulisan;

2) Menghargai dan bangga menggunakan bahasa indonesia sebagai bahasa persatuan dan bahasa negara;

3) Memahami bahasa indonesia dan menggunakannya dengan tepat dan kreatif untuk berbagai tujuan;

4) Menggunakan bahasa indonesia untuk meningkatkan kemampuan intelektual, serta kematangan emosional dan sosial;

5) Menikmati dan memanfaatkan karya sastra untuk memperluas wawasan, memperhalus budi pekerti, serta meningkatkan pengetahuan dan kemampuan berbahasa; dan

6) Menghargai dan membanggakan sastra indonesia sebagai khazanah budaya dan intelektual manusia indonesia (Sic). 
Penggunaan aspek kebahasaan dalam proses pembelajaran sering berhubungan satu sama lainnya. Menyimak dan membaca erat hubungan dalam hal bahwa keduanya merupakan alat untuk menerima komunikasi. Berbicara dan menulis erat hubungan dalam hal bahwa keduanya merupakan cara untuk mengekspresikan makna (Tarigan, 1986:10). Menulis merupakan kegiatan mengekspresikan informasi yang diterima dari proses menyimak dan membaca. Jadi, semakin banyak seseorang menyimak atau membaca semakin banyak pula informasi yang diterimanya untuk diekspresikan secara tertulis. Kemudian, Crimmon (dalam Kurniawan 2006:122) mengatakan bahwa:

"menulis merupakan suatu kegiatan yang produktif dan ekspresif. Dalam kegiatan menulis ini seorang penulis harus terampil memanfaatkan grafologi, struktur bahasa, dan kosakata. Keterampilan menulis digunakan untuk mencatat, merekam, meyakinkan, melaporkan, menginformasikan, dan mempengaruhi pembaca. Maksud dan tujuan seperti itu hanya dapat dicapai dengan baik oleh para pembelajar yang dapat menyusun dan merangkai jalan pikiran dan mengemukakannya secara tertulis dengan jelas, lancar, dan komunikatif. Kejelasan ini bergantung pada pikiran, organisasi, pemakaian dan pemilihan kata, dan struktur kalimat."

Berdasarkan beberapa pendapat di atas, dapat disimpulkan bahwa menulis merupakan salah satu keterampilan berbahasa yang dibutuhkan untuk meningkatkan kualitas pembelajaran. Dengan penguasaan keterampilan menulis, diharapkan siswa dapat mengungkapkan gagasan, pikiran, dan perasaan yang dimilikinya setelah menjalani proses pembelajaran dalam berbagai jenis tulisan, baik fiksi maupun nonfiksi. Asumsinya, pengungkapan tersebut merupakan peresapan, pemahaman, dan tanggapan siswa terhadap berbagai hal yang diperoleh dalam proses pembelajaran. Dengan demikian, segala informasi, ilmu pengetahuan, dan berbagai kecakapan yang diperoleh siswa dalam pembelajaran tidak akan sekedar menjadi hafalan yang mudah dilupakan sesaat setelah siswa menjalani tes.

Tujuan pembelajaran menulis belum dicapai secara maksimal oleh siswa. Menurut Trimantara (2005:1), penyebab terhadap tidak tercapainya tujuan pembelajaran menulis meliputi:

1) Rendahnya tingkat penguasaan kosa kata sebagai akibat rendahnya minat baca;

2) Kurangnya penguasaan keterampilan mikrobahasa, seperti penggunaan tanda baca, kaidah-kaidah penulisan, diksi, penyusunan kalimat dengan struktur yang benar, sampai penyusunan paragraf;

3) Kesulitan menemukan metode pembelajaran menulis yang sesuai dengan kondisi dan kemampuan siswa; serta

4) Ketiadaan atau keterbatasan media pembelajaran menulis yang efektif.

Karena pentingnya keterampilan menulis, pengembangan pembelajaran menulis perlu ditingkatkan. Peningkatan pembelajaran menulis dapat dilakukan melalui berbagai kegiatan. Purwo (1990:166-171) mengatakan kegiatan pengembangan pembelajaran menulis dapat dilakukan dengan kegiatan mengembangkan logika, melatih daya imajinasi, merangkai kata menjadi kalimat, dan merangkai kalimat menjadi paragraf. Hal ini dilakukan untuk mengaktifkan daya kreatif siswa dalam mengasah kecerdasan mareka.

Tes kemampuan menulis dapat divariasikan dalam berbagai bentuk tulisan. Tekniknya dapat disajikan data verbal, gambar, tabel, teks, peta, bagan. Dari data-data itu, siswa diminta untuk menulis sebuah karangan. Melalui kegiatan inilah kemampuan komunikatif siswa diukur secara terintegrasi (Mahmud, 2003:14).

Penggunaan teks wawancara sebagai alat bantu dalam mengembangkan karangan narasi akan membantu siswa untuk menceritakan kembali sesuatu peristiwa atau kejadian secara kronologis. Kegiatan seperti ini menyuburkan kesempatan kreatif bagi siswa dalam menampilkan gagasan dan keahlian memilih kata serta merangkainya menjadi kalimat. 
Penelitian ini mencoba mengukur kemampuan menulis siswa melalui "Kemampuan Mengembangkan Karangan Narasi Berdasarkan Teks Wawancara oleh Siswa Kelas I SMAN 8 Tangerang". Adapun tujuan utamanya adalah mendeskripsikan kemampuan menulis siswa kelas I SMAN 8 Tangerang melalui mengembangkan teks wawancara menjadi karangan narasi. Hal ini dilakukan karena selama ini siswa SMP masih dianggap belum mampu untuk menulis dengan alasan menulis itu cukup sulit untuk dikuasai oleh mereka, padahal siswa SMP ditutut memenuhi kemampuan yang memadai dalam menulis.

\section{Metode Penelitian}

Penelitian ini menggunakan metode deskriptif kuantitatif. Dari jumlah populasi sebanyak 190 siswa, diambil 48 responden. Sampel tersebut diambil secara acak pada lima kelas paralel. Penelitian ini dilaksanakan pada bulan agustus sampai dengan november 2018 di SMAN 8 Tangerang Banten.

\section{Hasil Penelitian}

Kemampuan siswa kelas I SMAN 8 Tangerang mengembangkan karangan narasi berdasarkan teks wawancara dapat dianalisis secara khusus. Secara khusus kemampuan itu diklasifikasikan atas aspek susbtansi dan aspek kebahasaan. Aspek susbtansi terdiri atas kemampuan menyusun kronologis dan kemampuan menyesuaikan isi narasi dengan teks wawancara. Sedangkan aspek kebahasaan meliputi kemampuan menggunakan ejaan, diksi, kalimat efektif, dan paragraf. Untuk mengetahui persentase rata-rata pada setiap aspek penilaian, setiap nilai rata-rata aspek tersebut dibagikan dengan skor maksimal lalu dikalikan dengan seratus.

\section{Kemampuan Menyusun Kronologis}

Kemampuan siswa kelas I SMAN 8 Tangerang menggunakan susunan kronologis dalam karangan narasi berdasarkan teks wawancara merupakan aspek utama dalam penilaian karangan siswa. Kemampuan ini dinilai melalui urutan gagasan yang dikembangkan dengan mengunakan urutan kronologis atau urutan waktu. Hubungan yang menyatakan waktu tersebut ditandai dengan penggunaan kata penghubung, seperti waktu, sewaktu, ketika, tatkala, tenggah, sedang, tiap kali, sebelum, setelah, sesudah, sehabis, sejak, semenjak, selagi, semasa, sementara, selama, setiap, setiap kali, sehingga, dan sampai.

Adapun skor untuk aspek ini adalah 30. Skor maksimal yang diperoleh mereka adalah 26 dan skor minimal 4. Berdasarkan tabel 7, nilai rata-rata kemampuan siswa kelas I SMAN 8 Tangerang dalam mengembangkan karangan narasi berdasarkan teks wawancara pada aspek menyusun kronologis adalah sebagai berikut.

$$
\begin{aligned}
& \bar{X}=\frac{\sum X i}{n} \\
& \bar{X}=\frac{620}{48} \\
& \bar{X}=12,91 \\
& \bar{X}=13
\end{aligned}
$$

Skor rata-rata aspek kemampuan menggunakan susunan kronologis adalah 12,91 dan dibulatkan menjadi 13. Skor ini terlihat belum memenuhi harapan karena skor maksimal yang diharapkan pada aspek ini adalah 30. Untuk mengetahui skor atau nilai rata-rata yang diperoleh siswa kelas I SMAN 8 Tangerang tentang kemampuan menyusun kronologis 
termasuk dalam kategori mana, nilai rata-rata tersebut diklasifikasian berdasarkan klasifikasi nilai Depdiknas. Oleh karena itu, nilai rata-rata ini (13) dibagikan dengan skor maksimal (30) lalu dikalikan dengan seratus (100). Jadi, nilai rata-rata tersebut adalah 43. Berdasarkan klasifikasi nilai Depdiknas, skor 43 termasuk dalam ketegori kurang. Dengan demikian, dapat disimpulkan bahwa kemampuan mereka dalam menyusun kronologis tergolong dalam kategori kurang.

\section{Kemampuan Menyesuaikan Isi Narasi dengan Teks Wawancara}

Selain kemampuan menyusun kronologis, kemampuan menyesuaikan isi narasi dengan teks wawancara juga merupakan aspek penilaian dari segi subsatansi. Penilaian ini juga dinyatakan dalam bentuk skor. Skor maksimal yang diperoleh mereka adalah 27 dan skor minimalnya 5. Berdasarkan tabel 7, diketahui bahwa jumlah skor nilai pada aspek ini adalah 756. Untuk mengetahui nilai rata-rata pada aspek ini, jumlah skor rata-rata tersebut dibagikan dengan jumlah siswa.

$$
\begin{aligned}
& \bar{X}=\frac{\sum X i}{n} \\
& \bar{X}=\frac{746}{48} \\
& \bar{X}=15,54 \\
& \bar{X}=16
\end{aligned}
$$

Jadi, skor rata-rata aspek ini adalah 16. Skor ini belum memenuhi harapan karena skor maksimal yang diharapkan pada aspek ini adalah 30. Untuk mengetahui skor atau nilai ratarata yang diperoleh siswa kelas I SMAN 8 Tangerang tentang kemampuan menyesuaikan isi narasi dengan teks wawancara termasuk dalam kategori mana, nilai rata-rata tersebut diklasifikasian berdasarkan klasifikasi nilai Depdiknas. Oleh karena itu, nilai rata-rata ini (16) dibagikan dengan skor maksimal (30) lalu dikalikan dengan seratus (100). Jadi, nilai rata-rata tersebut adalah 53. Berdasarkan klasifikasi nilai Depdiknas, skor 53 termasuk dalam ketegori kurang. Dengan demikian, dapat disimpulkan bahwa kemampuan mereka dalam menyesuaikan isi narasi dengan teks wawancara tergolong dalam kategori kurang.

\section{Kemampuan Menggunakan Bahasa}

Analisis data ini dilakukan dengan identifikasi kesalahan-kesalahan menggunakan bahasa. Setelah diidentifikasi, kesalahan-kesalahan berbahasa tersebut diklasifikasikan ke dalam kelompok-kelompok tertentu sehingga akan terlihat kesalahan-kesalahan berbahasa yang sering dilakukan oleh siswa. Kemampuan menggunakan bahasa dalam karangan siswa dianalisis meliputi kemampuan menggunakan ejaan, diksi, kalimat efektif, dan paragraf. Adapun prosedur pengolahan data dan gambaran mengenai kesalahan-kesalahan tersebut adalah sebagai berikut ini.

\section{a. Kemampuan Menggunakan Ejaan}

Kemampuan menggunakan ejaan dinyatakan dalam bentuk skor. Adapun skor untuk aspek ini adalah 10. Skor maksimal yang diperoleh mereka adalah 8 dan skor minimal 4 . Nilai rata-rata kemampuan siswa kelas I SMAN 8 Tangerang menggunakan ejaan dalam mengembangkan karangan narasi berdasarkan teks wawancara adalah sebagai berikut. 


$$
\begin{aligned}
& \bar{X}=\frac{\sum X i}{n} \\
& \bar{X}=\frac{255}{48} \\
& \bar{X}=5,31 \\
& \bar{X}=5
\end{aligned}
$$

Jadi, skor rata-rata aspek ini adalah 5,31 dan dibulatkan menjadi 5. Skor ini terlihat belum memenuhi harapan karena skor maksimal yang diharapkan pada aspek ini adalah 10. Untuk mengetahui skor atau nilai rata-rata yang diperoleh siswa kelas I SMAN 8 Tangerang tentang kemampuan menggunakan ejaan termasuk dalam kategori mana, nilai rata-rata tersebut diklasifikasikan berdasarkan klasifikasi nilai Depdiknas. Oleh karena itu, nilai rata-rata ini (5) dibagikan dengan skor maksimal (10) lalu dikalikan dengan seratus (100). Jadi, nilai rata-rata tersebut adalah 50 .

Berdasarkan klasifikasi nilai Depdiknas, skor 50 termasuk dalam ketegori kurang. Dengan demikian, dapat disimpulkan bahwa kemampuan mereka dalam menggunakan ejaan dengan tepat tergolong dalam kategori kurang.

Adapun kesalahan penggunaan ejaan yang ditemukan pada karangan siswa cukup beragam. Ketidaktepatan menggunaan ejaan tersebut meliputi (1) pemakaian huruf, (2) penulisan huruf, (3) penulisan kata, dan (4) pemakaian tanda baca. Adapun kesalahan yang sering dilakukan mereka adalah penggunaan tanda baca. Berikut ini akan disajikan beberapa contoh kesalahan penggunaan ejaan tersebut.

(1) Kadang - kadang mereka juga membantu orang tuanya.

(2) Bapak terus menerus bekerja.

(3) Kadang ** pembeli Pak Karim cukup banyak.

(4) ... anak tersebut bernama adi dan bapak penjual bakso.

(5) Waktu itu pak karim tidak memiliki perkerjaan.

(6) Dia Menanyakan tentang Pak Karim Menjual bakso.

(7) "Anak Bapak berapa orang dan sekolah dimana?"

(8) ....agar keuntunganpun bertambah besar.

(9) "Bapak senang di wawancarai."

(10) Bertanya apa!

Berdasarkan contoh-contoh di atas, terbukti bahwa kesalahan pengunaan ejaan yang dilakukan siswa sangat beragam. Kesalahan pada kalimat (1) adalah tanda hubung diikuti spasi pada bentuk pengulangan kadang-kadang. Tanda hubung dingunakan untuk merangkai kata ulang. Dalam pedoman ejaan, kata ulang harus dituliskan dengan dirangkaikan tanda hubung. Kesalahan kalimat (2) tidaka ada tanda hubung pada bentuk reduplikasi terus menerus. Selain itu, penggunaan angka dua atau bentuk $(* *)$ pada bentuk reduplikasi kalimat (3) juga tidak dibenarkan.

Kata adi, bapak pada kalimat (4), dan pak karim pada kalimat (5) merupakan nama orang dan kata penujuk kekerabatan. Bentuk tersebut ditulis dengan huruf awal kapital karena unsurunsur nama orang dan kata penujuk kekerabatan seperti bapak, ibu saudara, kakak, adik, paman yang dipakai dalam penyapaan dan pengacuan ditulis dengan huruf kapital dipakai sebagai huruf pertamanya. Selain itu, pada kalimat (6) kata Menanyakan dan Menjual seharusnya tidak ditulis denga huruf kapital. 
Karena di, ke, sering kita temukan serangkai, hal itu tentu melanggar kaidah ejaan. Kata di pada bentuk dimana pada kalimat (7) harus ditulis terpisah dari kata yang mengiringinya karena merupakan kata depan (preposisi). Biasanya bentuk di sebagai kata depan ini berfungsi menyatakan arah atau tempat dan merupakan jawaban di mana.

Partikel pun pada kalimat (8) ditulis terpisah dari kata yang mendahuluinya. Kemudian, bentuk di wawancarai pada kalimat (9) merupakan afiksasi. Afiks $d i$ - yang berfungsi sebagai awalan membentuk kata kerja pasif harus dituliskan serangkai dengan kata yang mengikutinya. Oleh karena itu, penulisan betuk tersebut tidak dipisahkan dari bentuk dasarnya.

Kalimat (10) merupakan kalimat tanya (introgatif). Seharusnya, bentuk apa ! tidak ditulis dengan menggunakan tanda seru (!), melainkan dengan tanda tanya (?). Selain kesalahan tersebut, penulisan tanda baca pun pada kalimat yang sama seharusnya juga tidak dipisahkan dengan kata yang mengikutinya karena bentuk tersebut harus ditulis serangkai dengan kata yang mengikutinya. Jadi, kalimat tersebut baru benar bila diubah, seperti berikut.

(1a) Kadang-kadang mereka juga membantu orang tuanya.

(2a) Bapak terus-menerus bekerja.

(3a) Kadang-kadang pembeli Pak Karim cukup banyak.

(4a) ... anak tersebut bernama Adi dan Bapak penjual bakso.

(5a) Waktu itu Pak Karim tidak memiliki perkerjaan.

(6a) Dia menanyakan tentang Pak Karim menjual bakso.

(7a) "Anak Bapak berapa orang dan sekolah di mana?"

(8a) ....agar keuntungan pun bertambah besar.

(9a) "Bapak senang diwawancarai."

(10a) Bertanya apa?

\section{b. Kemampuan Menggunakan Diksi}

Kemampuan menggunakan diksi merupakan salah satu subaspek penilaian pada aspek penggunaan kebahasaan dalam karangan siswa. Adapun skor maksimal yang diperoleh mereka adalah 8 dan skor minimalnya 2. Jumlah skor seluruhnya pada aspek ini adalah 220. Untuk mengetahui nilai rata-rata, jumlah skor tersebut dibagikan dengan jumlah sampel, seperti berikut.

$$
\begin{aligned}
& \bar{X}=\frac{\sum X i}{n} \\
& \bar{X}=\frac{220}{48} \\
& \bar{X}=4,58 \\
& \bar{X}=5
\end{aligned}
$$

Jadi, skor rata-rata kemampuan menggunakan diksi adalah 4,58 dan dibulatkan menjadi 5 . Skor ini terlihat belum memenuhi harapan karena skor maksimal yang diharapkan pada aspek ini adalah 10. Untuk mengetahui skor atau nilai rata-rata yang diperoleh siswa kelas I SMAN 8 Tangerang tentang kemampuan menggunakan diksi termasuk ke dalam kategori mana, nilai rata-rata tersebut diklasifikasikan berdasarkan klasifikasi nilai Depdiknas. Oleh karena itu, nilai rata-rata ini (5) dibagikan dengan skor maksimalnya (10) lalu dikalikan dengan seratus (100). Jadi, nilai rata-rata tersebut adalah 50. 
Berdasarkan klasifikasi nilai Depdiknas, skor 50 termasuk dalam ketegori kurang. Dengan demikian, dapat disimpulkan bahwa kemampuan mereka dalam menggunakan diksi tergolong dalam kategori kurang. Berdasarkan uraian di atas, penelitian ini memberi gambaran yang jelas bahwa para siswa banyak melakukan kesalahan dalam pemilihan kata (diksi). Kesalahan yang mereka lakukan seperti penggunaa bentuk superlatif, penggunaa kata yang mempunyai kemiripan makna atau fungsi secara berganda (poliesemi), dan penggunaan makna kesalingan secara berganda (resoprikal).

Beberapa kata yang kesalahan pemakaiannya cukup sering dilakukan adalah penggunaan kata-kata yang mirip secara berganda. Berikut ini adalah beberapa contoh kesalahan yang dilakukan siswa dalam memilih kata (diksi).

\section{Bentuk superlatif}

(1) Nama anak Pak Karim sangat bagus sekali...

(2) Anak Pak Karim termasuk anak yang sangat padai sekali.

Kalimat (1) salah karena kalimat tersebut merupakan bentuk superlatif. Bentuk superlatif merupakan bentuk yang mengandung arti 'paling' dalam suatu perbandingan. Bentuk tersebut dapat dihasilkan dengan suatu kata sifat ditambah kata-kata amat sangat, paling, sekali, atau imbuhan ter_ yang mengandung arti 'paling'. Jika kedua kata ini dingunakan sekaligus dalam suatu kalimat, terjadilah sebuah bentuk superlatif yang berlebihan. Jadi, kalimat tersebut baru benar bila diubah, seperti berikut.

(1a) Nama anak Pak Karim bagus sekali....

(1.b) Nama anak Pak Karim bagus cantik...

(2a) Anak Pak Karim termasuk anak yang padai sekali.

(2a) Anak Pak Karim termasuk anak yang sangat padai.

2. Penggunaa kata yang mempunyai kemiripan makna atau fungsi secara berganda (poliesemi)

(2) Lalu Adi bertaya kemudian, di mana Pak Karim membeli bahan-bahan yang diperlukan untuk membuat bakso tersebut.

Adi pun bertanya lagi...

(3) Anak itu langsung memulai mewawancaranya.

(4) Mereka berbicara sejak mulai siang.

(5) Pak Karim berjualan bakso hanya untuk mempertahankan kehidupan keluarganya saja.

(6) Banyak orang-orang membeli bakso di tempat Pak Karim.

Kesalahan kalimat (2), (3), (4), (5) (6), dan (7) adalah terdapat bentuk pleonasme, yaitu katakata atau frasa yang berlebihan/berganda maknanya. Bentuk ini bila dihilangkan salah satu unsurnya, maknanya tetap utuh. Kalimat- kalimat tersebut baru benar bila diubah, seperti berikut.

(3a) Lalu, Adi bertaya, "Di mana Pak Karim membeli bahan-bahan yang diperlukan untuk membuat bakso tersebut."

(3b) Kemudian, Adi bertaya, "Di mana Pak Karim membeli bahan-bahan yang diperlukan untuk membuat bakso tersebut."

(4a) Adi pun bertanya....

(4b) Adi bertanya lagi....

(5a) Anak itu memulai mewawancaranya.

(5b) Anak itu langsung mewawancaranya.

(6a) Mereka berbicara mulai siang... 
(6b) Mereka berbicara sejak siang...

(7a) Pak Karim berjualan bakso hanya untuk mempertahankan kehidupan keluarganya.

(7b) Pak Karim berjualan bakso untuk mempertahankan kehidupan keluarganya saja.

(8a) Banyak orang membeli bakso di tampat Pak Karim.

(8b) Orang-orang membeli bakso di tampat Pak Karim.

3. Penggunaan makna kesalingan secara berganda (resiprokal)

(8) Pak Karim dan anaknya saling bantu- membantu.

Kesalahan pada kalimat (8) adalah penggunaan bentuk bahasa yang mengandung arti bebalasan. Bentuk ini dihasilkan dengan menggunakan kata saling dengan kata ulang beribuhan. Akan tetapi, jika ada bentuk yang berarti 'berbalasan' itu dengan cara pengulangan kata sekaligus dengan pengunaan kata saling sehingga terjadi bentuk resiproka, seperti disebutkan pada kalimat (8). Jadi, kalimat tersebut baru benar bila diubah, seperti berikut.

(8a) Pak Karim dan anaknya saling mambantu.

(8b) Pak Karim dan anaknya bantu-mambantu.

Selain itu, penggunaan kata katakan pada kalimat (9) dan jam pada kalimat (10) berikut ini juga tidak tepat.

(9) Hal yang pertama ia katakan adalah berbasa-basi.

(10) Bapak buka warung pada pukul 09.00 dan bapak tutup jam 19.00 malam.

Seharusnya, kata tersebut 'katakan' diganti dengan kata 'lakukan'. Kata jam yang berarti menujukkan rentang waktu atau benda dan pada kalimat (10), seharusnya juga diganti dengan kata pukul yang berarti menujukkan waktu. Jadi, perbaikan terhadap kalimat-kalimat tersebut adalah sebagai berikut.

(9a) Hal yang pertama ia lakukan adalah berbasa-basi.

(10a) Bapak buka warung mulai pukul 09.00 sampai pukul 19.00.

Berdasarkan data penelitian dan sampel kesalahan tersebut, kemampun mereka menggunakan ketepatan pilihan kata, seperti membedakan secara cermat denotasi dari konotasi, membedakan dengan cermat kata-kata yang hampir bersinonmi, dan membedakan kata umum dan kata khusus masih kurang. Padahal, ketepatan pilihan kata (diksi) menentukan kesanggupan sebuah kata untuk menimbulkan gagasan-gagasan yang tepat.

\section{c. Kemampuan Menggunakan Kalimat Efektif}

Sama halnya dengan kemampuan menggunakan ejaan dan diksi, kemampuan menggunakan kalimat efektif juga merupakan salah satu aspek penilaian dari segi penggunaan bahasa dalam karangan siswa. Skor maksimal yang diperoleh mereka pada aspek ini adalah 7 dan skor minimal 2. Adapun nilai rata-rata kemampuan menggunakan kalimat efektif adalah sebagai berikut.

$$
\begin{aligned}
& \bar{X}=\frac{\sum X i}{n} \\
& \bar{X}=\frac{182}{48} \\
& \bar{X}=3,79 \\
& \bar{X}=4
\end{aligned}
$$


Skor rata-ratanya adalah 3,79 dan dibulatkan menjadi 4. Skor ini terlihat belum memenuhi harapan karena skor maksimal yang diharapkan pada aspek ini adalah 10. Untuk mengetahui skor atau nilai rata-rata yang diperoleh siswa kelas I SMAN 8 Tangerang tentang kemampuan menggunakan kalimat efektif termasuk dalam kategori mana, nilai rata-rata tersebut diklasifikasikan berdasarkan klasifikasi nilai Depdiknas. Oleh karena itu, nilai ratarata (4) dibagikan dengan skor maksimal (10) lalu dikalikan dengan seratus (100). Jadi, nilai rata-rata tersebut adalah 40 .

Berdasarkan klasifikasi nilai Depdiknas, skor 40 termasuk dalam ketegori kurang. Dengan demikian, dapat disimpulkan bahwa kemampuan mereka dalam menggunakan kalimat efektif tergolong dalam kategori kurang.

Kalimat-kalimat yang dibuat siswa umunya merupakan kalimat tidak efektif. Kalimat tersebut tidak memenuhi syarat-syarat kalimat efektif seperti unsur-unsur kalimat tidak jelas, bagian-bagian kalimat tidak sejajar, bagian kalimat banyak yang dipenggal, bagian-bagian yang sama sering digunakan, dan sebagian kalimat tidak disusun menurut kaidah bahasa tersebut. Adapun kesalahan-kesalahan yang sering dilakukakan berupa ketidaklengkapan fungsi kalimat yang meliputi tidak adanya subjek, predikat yang tidak jelas, kalimat berbelitbelit, pemengalan kalimat, penghilangan konjungsi, dan penggunaan dua konjungsi dalam kalimat majemuk bertingkat. Karena hal tersebut, kalimat-kalimat yang ditata mereka mengandung lebih dari satu kesatuan informasi atau tidak lengkapnya informasi. Oleh karena itu, kalimat yang ditata mereka sering menimbulkan kerancuan dan ketidaktepatan makna. Berikut ini adalah sampel ketidakefektifan kalimat tersebut beserta perbaikannya.

1. Pemisahan bagian kalimat majemuk

(1) Waktu itu Bapak tidak memiliki pekerjaan. Karena pabrik tempat Bapak

bekerja bangkrut.

(2) Mereka tetap sekolah. Walaupun Bapak harus bekerja keras.

Kalimat di atas salah kerena unsur ketarangan pada kalimat tersebut yang ditandai dengan kata karena dan walaupun dipisah menjadi bagian tersendiri. Dengan kata lain, kalimat tersebut dipenggal. Kalimat yang dipenggal itu masih mempuyai hubungan gantung dengan Kalimat lainya. Kalimat yang memepunyai hubungan gantung itu disebut anak kalimat, sedangkan kalimat yang digantunginya disebut induk kalimat. Jika kalimat tungga diawali kata penghubung, bagian kalimat itu akan menjadi anak kalimat yang tidak memiliki induk kalimat. Kalimat tersebut menjadi benar apabila unsur keterangan itu tidak berdiri sendiri karena bukan merupakan kalimat baru.

(1a) Waktu itu Bapak tidak memiliki pekerjaan karena pabrik tempat Bapak bekerja bangkrut.

(1b) Karena pabrik tempat Bapak bekerja bangkrut, waktu itu Bapak tidak memiliki pekerjaan.

(2a) Mereka tetap sekolah walaupun Bapak harus bekerja keras.

(2a) Walaupun Bapak harus bekerja keras, mereka tetap sekolah.

2. Penghilangan konjungsi

(3) Mendengar jawaban dari Pak Karim, Adi merasa kasihan kepada Pak Karim.

(4) Pulang sekolah, mereka membantu Bapak.

Kalimat di atas salah karena kata penghubung penanda anak kalimat, seperti ketika, setelah, dan agar seharusnya dinyatakan secara gamblang di depan anak kalimat . Jadi, pembenaran kalimat tersebut adalah sebagai berikut.

(3a) Setelah mendengar jawaban dari Pak Karim, Adi merasa kasihan kepada Pak Karim.

(3b) Adi merasa kasihan kepada Pak Karim setelah mendengar jawabannya.

(4a) Ketika pulang sekolah, mereka membantu Bapak. 
(4b) Mereka membantu Bapak ketika pulang sekolah.

3. Unsur kalimat tidak jelas

(5) Yang kedua yang namanya Nina yang sekolah di SD kelas 3.

(6) Bapak yang menjual bakso itu.

(7) Anak bapak itu yang pertama yang bernama Rudi yang duduk di kelas 1 SMP dan anak yang kedua baru duduk di kelas 3 SD.

(8) Pak Karim akan mengolah bakso dengan istrinnya.

Unsur kalimat di atas tidak jelas Kalimat (5) tidak ada subjek dan predikat. Padahal kedua unsur tersebut wajib hadir dalam sebuah kalimat . Kalimat (6) merupakan kalimat yang belum berpredikat.

Kalimat (7) merupakan kalimat yang belum berpredikat juga. Hal ini terjadi akibat adanya keterangan subjek yang beruntun, kemudian keterangan itu diberi keterangan lagi sehingga penulisnya lupa kalau kalimat yang ia buat itu belum lengkap, belum berpredikat, misalnya sebelum predikat tersebut dicantumkan kata yang atau dan sehingga kalimat predikat menjadi hilang. Jadi, penghilangan kata yang pada kalimat (7) dapat menghasilkan kalimat yang benar atau kalimat yang mengandung subjek dan predikat. Subjek kalimat ini adalah anak Bapak itu pertama, predikatnya bernama, Rudi pelengkap, dan yang duduk di kelas 1 SMP dan anaknya yang kedua baru duduk di kelas 3 SD merupakan pewatas pelengkap. Jadi, perbaikan kalimat tersebut adalah sebagai berikut.

Kalimat (8) tidak memiliki predikat karena didahului kata preposisi akan. Fungsi predikat kabur bila diadahului preposisi. Seharusnya preposisi tersebut (akan) tidak dinggunakan. Jadi, alternatif perbaikan kalimat tersebut adalah sebagai berikut.

(5a) Anak kedua bernama Nina yang sekolah di kelas III SD.

(5b) Nina yang sekolah di kelas III SD merupakan anak kedua.

(6a) Bapak penjual bakso itu.

(7a) Anak Bapak itu bernama Rudi yang duduk di kelas 1 SMP dan anak yang kedua baru duduk di kelas III SD.

(8a) Pak Karim mengolah bakso dengan isterinya.

(8a) Bakso itu diolah oleh Pak Karim dan istrinya.

4. Penggunaan dua konjungsi dalam kalimat majemuk bertingkat

(9) Meskipun Pak Karim berkeinginan anaknya sukses tetapi itu tidak dengan mudah membiayai pendidikan mereka.

Penggunaan pasangan kata pada kalimat (9) meskipun...tetapi... pada kalimat tersebut akan menimbulkan kerancuan pikiran. Kata meskipun menyatakan 'alahan', sedangkan kata tetapi menyatakan 'perlawanan'. Penggabungan kedua kata penghubung itu dalam satu kalimat tentulah menimbulkan hubungan pikiran yang tidak logis. Perbaikan kalimat tersebut adalah sebagai berikut.

(9a) Pak Karim berkeinginan anaknya sukses tetapi itu tidak mudah membiayai pendidikan mereka.

(9b) Meskipun Pak Karim berkeinginan anaknya sukses, itu tidak mudah membiayai pendidikan mereka.

5. Kaidah penalara

(10) Karena pabrik bapak mulai bangkrut bapak-bapak susah mendapatkan azpekerjaan.

Kalimat di atas tidak baku. Kesalahan pertama, penghubung kalimat tersebut seharusnya digunakan tanda koma (,) untuk memisahkan anak kalimat dengan induk kalimat yang didahului anak kalimat. Kesalahan kedua, kata karena seharusnya diganti dengan setelah. Selain itu, kalimat tersebut juga tidak bernalar. Hal ini terjadi karena pengulangan kata Bapak-bapak. Mustahil Bapak-bapak susah mendapatkan pekerjan karena pabrik Pak Karim bangkrut. Jadi, alternatif perbaikan kalimat tersebut adalah sebagai berikut. 
(10a) Setelah pabrik Bapak mulai bangkrut, Bapak susah mendapatkan pekerjaan.

(10a) Bapak susah mendapatkan pekerjaan setelah pabrik Bapak bangkrut.

6. Kalimat berbelit-belit

(11) Pak Karim berenjual bakso dengan istri dan juga dua orang anaknya, kedua anaknya itu sudah sekolah, yang satu bersekolah di SMP yang kedua sekolah di SD.

Karena beberapa gagasan yang disampaikan digabungkan menjadi satu kalimat, kalimat di atas sukar dipahami. Padahal, jika dipilah-pilah menjadi bagian- bagian yang sejalan dengan pokok pikiran yang dikemukakan, kalimat tersebut mudah dipahami. Jadi, perbaiakan terhadap kalimat tersebut adalah sebagai berikut.

(11a) Pak Karim berenjual bakso dengan istri dan juga dua orang anaknya. Kedua anaknya itu sudah sekolah. Anak yang pertama sekolah di SMP dan anak kedua sekolah di SD.

\section{d. Kemampuan Menyusun Paragraf}

Selain kemampuan menggunakan ejaan, diksi, dan kalimat efektif, kemampuan menyusun paragraf juga merupakan salah satu bagian dari penilaian pada aspek kebahasaan. Adapun skor untuk aspek ini adalah 10. Skor maksimal yang diperoleh mereka adalah 5 dan skor minimal 2. Berdasarkan tabel 7, nilai rata-rata kemampuan siswa kelas I SMAN 8 Tangerang pada aspek ini adalah sebagai berikut.

$$
\begin{aligned}
& \bar{X}=\frac{\sum X i}{n} \\
& \bar{X}=\frac{154}{48} \\
& \bar{X}=3,16 \\
& \bar{X}=3
\end{aligned}
$$

Skor rata-rata pada aspek ini adalah 3,16 dan dibulatkan menjadi 3. Skor ini terlihat belum memenuhi harapan karena skor maksimal yang diharapkan pada aspek ini adalah 10. Untuk mengetahui skor atau nilai rata-rata yang diperoleh siswa kelas I SMAN 8 Tangerang tentang kemampuan menyusun paragraf termasuk dalam kategori mana, nilai rata-rata tersebut diklasifikasian berdasarkan klasifikasi nilai Depdiknas. Oleh karena itu, nilai rata-rata ini (3) dibagikan dengan skor maksimalnya (10) lalu dikalikan dengan seratus (100). Jadi, nilai ratarata tersebut adalah 30 .

Berdasarkan klasifikasi nilai Depdiknas, skor 30 termasuk dalam ketegori sangat kurang. Dengan demikian, dapat disimpulkan bahwa kemampuan mereka dalam menyusun paragraf tergolong dalam kategori sangat kurang. Bardasarkan uraian di atas, nilai rata-rata yang diperoleh siswa pada aspek penggunaan paragaraf merupakan nilai terendah. Kesalahan yang sering terjadi adalah tidak adanya kesatuan gagasan dalam paragraf tersebut. Selain itu, ada pula karangan siswa yang terdiri lebih dari satu paragraf, tetapi paragraf tersebut belum belum memenuhi sayarat-sayarat paragraf yang baik. Dengan kata lain, paragraf itu belum ada kesatuan atau keutuhan gagasan, kepaduan susunan (koherensi), dan kelengkapan atau ketuntasan gagasan. Adapun contoh kesalahan penggunaan paragraf adalah sebagai berikut. 


\section{Contoh 1}

(1) Pak Karim harus membuka usaha nya lebih besar lagi, untuk mebiayai pendidikan anaknya . (2) Adi memberi saran "Bapak tidak usah kuatir, sekarang bantuan untuk pendidikan kita banyak sekali .(3) Mereka yang pinter akan diberikan beasiswa, malah ada yang disekolahkan keluar Negeri . (4) Kadang ** pembeli pak Karim cukup banyak, itulah yang menjadi suka dan kadang ** pak karim merasa kesepian, itulah dukanya . (5) Contoh (2) Baiklah terimakasih pak, ya , nak .
(1) Pak karim sekarang tidak kuatir lagi. (2) Sebabnya bantuan untuk pendidikan sekarang sudah meningkat dan sering diberi beasiswa, bahkan ada juga dikirimkan ke luar negeri. (3) Sukanya Pak Karim jika pembeli ramai. Contoh 3

Pada suatu hari ada seorang bakso yang sedang di wawan cari oleh seorang para kariawan. Dia bertanya kepada bapak itu. Bertanya apa!

Parangraf (1) di atas tidak memiliki kesatuan gagasan. Paragraf tersebut terdapat bukan satu gagasa utama, melainkan empat gagasa utama atau topik. Topik tersebut meliputi (1) "Pak Karim harus membuka usahanya yang lebih besar lagi", kalimat (2) dan (3) membicarakan saran si Adi untuk Pak Karim", kalimat (4) membicarkan tentang suka dan duka pak Karim." Selain itu, kalimat (5) Baiklah terimakasih pak, ya, nak juga merupakan gagasan baru. Gagasan pragraf ini bisa dikembangkan menjadi beberapa paragraf baru, seperti berikut. Perbaikan (1a)

Adi memberi saran kepada Pak Karim. Pak Karim harus membuka usahanya yang lebih besar lagi untuk mebiayai pendidikan anaknya. Selain itu, dia juga menyarankan agar Pak Karim tidak usah kuatir dengan biaya pendidikan sekarang karena biaya untuk pendidikan kita itu sangat banyak. Sebagian mereka yang pintar disekolahkan keluar negeri.

Perbaikan (1b)

Kadang-kadang pembeli bakso Pak Karim cukup banyak. Hal itu membuat dia menjadi senang. Sebaliknya, jika pembelinya sepi, beliau juga ikut sepi. Hal ini sudah biasa beliau alami.

Perbaikan (1c)

Si Adi mewawancarai Pak Karim hampir satu jam. Akhirnya, dia mengakhiri wawancaranya dengan mengucapkan terima kasih kapada Pak Karim. Pak Karim pun menjawab ucapan si Adi dengan senang hati.

Paragraf (2) terdiri atas dua gagasan utama. Kalimat (1) "Pak karim sekarang tidak kuatir lagi." dan (2)“ Sebabnya bantuan untuk pendidikan sekarang sudah meningkat dan sering diberi beasiswa, bahkan ada juga dikirimkan ke luar negeri." membicarakan saran untuk Pak Karim. Kemudian, kalimat (3) "Sukanya Pak Karim jika pembeli ramai." membicarakan tentang kesenangan Pak Karim.

Perbaikan (2a)

Pak Karim sekarang tidak usah kuatir lagi. Bantuan pendidikan kita sudah meningkat atau sering diberi beasiswa. Sebagian mereka yang pintar disekolahkan ke luar negeri.

Meskipun terdiri lebih dari satu kalimat, paragraf (3) belum tuntas atau tidak lengkap. Pikiran utama dalam paragraf tersebut belum dikembangan secara memadai. Paragraf tersebut lebih bersifat garis besar. Dalam kalimat tersebut belum ada kalimat penjelas yang memaparkan tentang apa si pewawancara bertanya dan siapa penjual bakso itu atau pewawancara tersebut. 
Perbaikan (3a)

Pada suatu hari, ada seorang penjual bakso diwawancarai oleh seorang pewawancara. Penjual bakso itu bernama Adi dan pewawancaranya bernama Pak Karim. Dia bertanya kepada Bapak itu. Petanyaannya dimulai dengan menanyakan kisah perjalanan penjual bakso tersebut.

Umunya paragraf yang dikembangaka siswa tidak memiliki peryaratan sebuah paragraf yang baik, seperti tidak adanya kesatuan, kohesi atau penyatuan, kecukupan pengembangan, susuan yang berpola. Berdasarkan uraian di atas, jelas bahwa mereka belum mampu mengembangkan karangan narasi berdasarkan teks wawancara sebagaimana diharapkan. Ketidakmampuan ini terlihat pada aspek substansi dan aspek kebahasaan. Aspek substasi yang paling dominan terlihat adalah pada aspek kemampuan menyusun kronologis. Sedangkan aspek kebahasaan, para siswa umumnya belum mampu menggunakan ejaan secara benar, menggunakan diksi secara tepat, menata kalimat dengan efektif, dan menyusun paragraf dengan baik. Pemakaian unsur ejaan, umumnya tanda baca dalam karangan siswa banyak ditemukan kesalahan. Penggunaan diksi pun masih kurang tepat. Penggunaan kalimat kebanyakan merupakan kalimat-kalimat yang tidak efektif. Selain itu, paragraf yang digunakan merupakan paragraf yang tidak memiliki syarat paragraf yang baik.

Dengan demikian, dapat disimpulkan bahwa ketidakmampuan siswa di SMA 8 Tangerang ini dalam mengembangkan karangan narasi berdasarkan teks wawancara terletak pada kedua aspek tersebut. Pertama adalah aspek substansi, yaitu ketidakmampuan mahami jenis karangan terutama karangan narasi. Selain itu juga karena ketidakmampuan mereka menggunakan bahasa Indonesia yang benar sebagai sarana komunikasi tulis.

\section{Kesimpulan dan Rekomendasi}

Berdasarkan hasil penelitian yang telah dibicarakan pada bab III di atas, dapat disimpulkan bahwa kemampuan siswa kelas I SMAN 8 Tangerang mengembangkan karangan narasi berdasarkan teks wawancara torgolong kurang. Hal ini dilihat melalui nilai rata-rata yang diperoleh siswa kelas I SMAN 8 Tangerang secara umum, yaitu berada pada kategori kurang (40-54). Dilihat dari segi persentase, siswa memperoleh nilai pada kategori sangat baik tidak ada sama sekali, kategori baik 6 orang atau 12,5\%, kategori cukup 10 orang atau 20,8\%, kategori kurang 7 orang atau $14,5 \%$ dan sisanya 25 orang atau $52,0 \%$ berada pada ketegori sangat kurang.

Adapun rincian nilai rata-rata kemampuan siswa kelas I SMAN 8 Tangerang mengembangkan karangan narasi berdasarkan teks wawancara secara khusus adalah sebagai berikut.

1) Nilai rata-rata menyusun kronologis tergolong dalam kategori kurang, yaitu 43;

2) Nilai rata-rata menyesuaikan isi narasi dengan teks wawancara tergolong dalam kategori kurang, yaitu 53;

3) Nilai rata-rata menggunakan ejaan tergolong dalam kategori kurang, yaitu 5;

4) Nilai rata-rata kemampuan mereka dalam menggunakan diksi tergolong dalam kategori kurang, yaitu 50.

5) Nilai rata-rata menggunakan kalimat efektif tergolong dalam kategori kurang, yaitu 40;

6) Nilai rata-rata menyusun paragraf tergolong dalam kategori sangat kurang, yaitu 30 .

Ketidakmampuan siswa kalas I SMAN 8 Tangerang mengembangkan karangan narasi berdasarkan teks wawancara meliputi aspek substansi dan aspek kebahasaan. Pada aspek substasi, kesalahan yang dominan adalah aspek menyusun kronologis. Adapun aspek kemampuan menggunakan bahasa, para siswa umumnya belum mampu menggunakan ejaan 
secara benar, menggunakan diksi secara tepat, menata kalimat dengan efektif, dan menyusun paragraf dengan baik.

Kemampuan menulis siswa kelas I SMAN 8 Tangerang belum maksimal. Oleh karena itu, siswa perlu mendapatkan pembelajaran yang intensif dalam pembelajaran menulis. Hal ini dapat dilakukan dengan meningkatkan pembelajaran menulis. Peningkatan pembelajaran menulis dapat dilakukan melalui berbagai cara, seperti

1) meningkatkan tingkat penguasaan kosa kata dengan banyak baca;

2) menguasai keterampilan mikrobahasa, seperti penggunaan tanda baca, kaidahkaidah penulisan, diksi, penataan kalimat dengan struktur yang benar, dan penggunaan paragraf yang baik;

3) menemukan metode pembelajaran menulis yang sesuai dengan kondisi dan kemampuan siswa; serta

4) menggunakan media pembelajaran menulis yang efektif.

Selain itu, untuk meningkatkan keterampilan menulis, guru haruss banyak memberikan latihan menulis kepada siswa. Latihan itu divariasikan dalam berbagai bentuk. Tekniknya disajikan data verbal, gambar, tabel, teks, peta, bangan. Dari data-data tersebut, siswa diminta untuk menulis sebuah karangan. Dengan melakukan kegiatan seperti ini, siswa terlatih untuk mengembangkan logika, daya imajinasi, dan kemampuan menggunakan bahasa yang benar. Hal ini dilakukan untuk mengaktifkan daya kreatif siswa dalam mengasah kecerdasan mereka.

\section{Referensi}

Dewi, S. P. (2017). PENGGUNAAN MEDIA GAMBAR SERI UNTUK MENINGKATKAN KEMAMPUAN MENULIS SEDERHANA BERBENTUK NARASI SISWA KELAS II SEKOLAH DASAR (Doctoral dissertation, Universitas Pendidikan Indonesia).

Djamarah, Saiful Bahri. 2000. Guru dan Anak Dididik dalam Pambelajaran Edukatif. Jakarta: Rineka Cipta.

Fauzi, A. M. (2017). PENERAPAN METODE COOPERATIVE INTEGRATED READING AND COMPOSITION (CIRC) DALAM PEMBELAJARAN SEJARAH UNTUK MENUMBUHKAN MINAT MENULIS NARASI SEJARAH: Penelitian Tindakan Kelas di Kelas XI MIPA 4 SMA Negeri 8 Bandung (Doctoral dissertation, Universitas Pendidikan Indonesia).

Gani, Erizal. 2001. Pemberdayaan Pengajaran Menulis; Upaya Menumbuhkembangkan Kemahiran Menulis Sejak Dini. Denpasar: Balai Bahasa Denpasar

Keraf, Gorys. 1987. Argumentasi dan Narasi. Jakarta: PT Gramedia.

Lestari, T., \& Sarah, Y. (2016). PENERAPAN MODEL KOOPERATIF TIPE CONCEPT SENTENCE UNTUK MENINGKATKAN KETERAMPILAN MENULIS KARANGAN NARASI SISWA KELAS IV SEKOLAH DASAR (Doctoral dissertation, Universitas Pendidikan Indonesia).

Sari, A. A. (2018). KORELASI ANTARA KEMAMPUAN MENYIMAK TRAILER FILM DENGAN KEMAMPUAN MENULIS KARANGAN NARASI BAHASA PERANCIS MAHASISWA (Doctoral dissertation, Universitas Pendidikan Indonesia).

Siregar, S. (2017). MENINGKATKAN KETERAMPILAN SISWA DALAM MENULIS KARANGAN NARASI MENGGUNAKAN MODEL MIND MAPPING PADA MATA PELAJARAN BAHASA INDONESIA DI KELAS V SD NEGERI 107828 ARAS PANJANG TAHUN AJARAN 2015/2016 (Doctoral dissertation, UNIMED). 